\title{
Pengaruh Model Pembelajaran Attention, Relevance, Confidence, Satisfaction (ARCS) Tehadap Hasil Belajar IPA Siswa Kelas IV Sekokah Dasar
}

\author{
I Made Dodik Septiawan', Anak Agung Gede Agung ${ }^{2}$ \\ ${ }^{1}$ Prodi Pendidikan Guru Sekolah Dasar, Universitas Pendidikan Ganesha \\ ${ }^{2}$ Prodi Teknologi Pendidikan, Universitas Pendidikan Ganesha \\ e-mail: madedodik18@gmail.com ${ }^{1}$, agungtps2056@gmail.com²
}

\begin{abstract}
Abstrak
Penelitian ini dilatarbelakangi oleh rendahnya hasil belajar IPA yang ditemukan pada siswa kelas IV SD Gugus V Kecamatan Sukasada Kabupaten Buleleng. Oleh karena itu, penelitian ini bertujuan untuk mengetahui pengaruh model pembelajaran Attention, Relevance, Confidence, Satisfaction (ARCS) terhadap hasil belajar IPA siswa kelas IV SD Gugus V Kecamatan Sukasada Kabupaten Buleleng tahun pelajaran 2019/2020. Penelitian ini merupakan penelitian kuasi eksperimen dengan desain non-equivalent post-test only control group desaign. Populasi dalam penelitian ini yaitu seluruh kelas IV SD Gugus Kecamatan Sukasada Kabupaten Buleleng yang berjumlah 236 orang siswa. Sampel penelitian ini yaitu kelas IV SDN 2 Panji sebagai kelompok eksperimen dengan jumlah siswa 30 orang, dan kelas IV SDN 4 Panji sebagai kelompok kontrol dengan jumlah siswa 33 orang dipilih dengan teknik kluster random sampling. Metode pengumpulan data yang digunakan adalah metode tes yaitu tes pilihan ganda. Data yang diperoleh dianalisis menggunakan analisis statistik deskriptif dan statistik inferensial. Rata-rata hasil belajar IPA pada kelompok eksperimen lebih tinggi dibandingkan dengan kelompok kontrol $(18,83>16,12)$. Berdasarkan analisis data menggunakan uji-t menunjukkan thitung $=4,37$ dan tabel $=2,00$ dengan taraf signifikansi $5 \%$. Berdasarkan keriteria pengujian $t_{\text {hitung }}>t_{\text {tabel }}(4,37>2,00)$, sehingga $H_{0}$ ditolak dan $H_{1}$ diterima. Dengan demikian dapat disimpulkan bahwa terdapat pengaruh yang signifikan model pembelajaran Attention, Relevance, Confidence, Satisfaction (ARCS) terhadap hasil belajar siswa kelas IV SD Gugus V Kecamatan Sukasada Kabupaten Buleleng tahun pelajaran 2019/2020.
\end{abstract}

Kata kunci: $A R C S$, hasil belajar, dan IPA.

\begin{abstract}
This research is motivated by the low level for the score of science subject in the elementary school for the grade IV in Gugus V Sukasada Sub-district, Buleleng Distric. The purpose of this study to interaction of learning models Attention, Relevance, confidence, and Satisfaction (ARCS) on the learning outcomes of science subject for students in grade IV on Gugus V in the Sukasada sub-district, Buleleng Distric on academic year 2019/2020. The kind of study is a quasi-experimental study with a nonequivalent control group design post-test only. The population on this study were all class IV students on the elementary in Gugus V in Sukasada sub-district, Buleleng Distric who received 236 students. The sample of this research is class IV SDN 2 Panji as an experimental group with 30 students, and class IV SDN 4 Panji as a control group with 33 students selected by simple cluster sampling technique. The data collection method used multiple-choice test and analyzed by descriptive statistical analysis and inferential statistics. The average science learning outcomes in the experimental group were higher than in the control group (18.83>16.12). Based on data analysis using the t-test showed
\end{abstract}

\footnotetext{
*Corresponding author.

Received 20 April 2020, Accepted 20 Juni 2020; Available online 5 Juli 2020 (C) 2020 MI All Rights Reserved
} 
tcount $=4.37$ and ttable $=2.00$ with a significance level of $5 \%$. Based on trials tcount $>t$ table (4.37> 2.00), then $\mathrm{HO}$ is rejected and $\mathrm{H} 1$ is accepted. Thus, the conclusion of this study is a significant influence on the learning model of Attention, Relevance, Confidence, Satisfaction (ARCS) on the learning outcomes of Grade IV on Gugus V in the Sukasada Sub-district, Buleleng District on academic year 2019/2020. Furthermore, for other researcher references can be made for further research and study.

Keywords: ARCS, learning outcomes, and science

\section{Pendahuluan}

Menciptakan pendidikan bermutu perlunya diimbangi dengan pembelajaran yang bermakna. Dalam pembelajaran guru memberikan stimulus yang disusun sedemikian rupa untuk membentuk tingkah laku serta niat belajar siswa yang baik. Setiap pembelajaran memiliki tujuan yang jelas harus dicapai guna meningkatkan hasi belajar siswa. Pembelajaran merupakan proses pemberian bimbingan dan bantuan kepada siswa dalam melakukan proses belajar (Pane \& Dasopang, 2017). Demikian juga dalam pembelajaran IImu Pengetahuan Alam (IPA) yang merupakan satu dari lima muatan pelajaran pokok yang dipelajari di Sekolah Dasar, menekankan pada penguasaan siswa terhadap pengetahuan tentang alam sekitar, sikap ilmiah yang harus ditunjukkan siswa dalam setiap proses belajarnya. Pembelajaran IPA selalu menekankan implementasi hakikat IPA.

Hakikat IPA meliputi sebagai sikap, proses, produk, dan aplikasi. Trianto (dalam Mawardi \& Mariati, 2016) menyatakan bahwa, terdapat empat unsur penting dalam hakikat IPA yang terdiri dari sikap merupakan rasa ingin tahu tentang fenomena alam, berbagi benda, makhluk hidup serta bersifat open ended hubungan sebab akibat yang menunjukkan masalah baru yang dapat dipecahkan melalui prosedur yang benar. Proses merupakan prosesdur pemecahan masalah dengan menggunakan metode ilmiah meliputi, penyusunan hipotesis, perencanaan eksperimen atau percobaan, evaluasi, pengukuran, dan penarikan kesimpulan. Produk yaitu berupa fakta, prinsip, teori dan hukum. Aplikasi merupakan penerapan metode ilmiah dan konsep IPA dalam kehidupan sehari-hari. Unsur-unsur tersebut merupakan ciri-ciri dasar dari IPA yang bersifat untuh dan tidak dapat dipisahkan.

IPA berdasarkan hakikatnya merupakan pelajaran yang memberikan pengalaman langsung terhadap siswa melalui berbagai macam tahapan logis dalam melakukan penemuan baru tentang alam (Ariyanto, 2016). Nariastini et al., (2015) menyatakan bahawa, IPA adalah ilmu pengetahuan yang memiliki konsep hidup harmonis dengan alam sebagai dasar perkembangan teknologi maju akan memberikan peran terhadap meningkatkan SDM yang handal dan bermutu. Berdasarkan pendapat ahli di atas, dapat disimpulkan IPA merupakan salah satu cabang ilmu yang memberikan pengalaman langsung dalam melakukan penemuan baru tentang alam.

Pembelajaran IPA di SD sebagai awal siswa mempelajari tentang alam, melestarikan dan menjaga alam dengan berbagai pengetahuan baru yang akan diterima dalam pembelajaran. Senada dengan pendapat tersebut, Putra (2017) menyatakan bahwa, pembelajaran IPA di SD/MI merupakan dasar atau sebagai pondasi awal siswa dalam penguasaan pengetahuan, keterampilan, dan sikap ilmiah dalam pembelajaran IPA. Setiyawati \& Rocmah (2017) menyatakan bahawa, pembelajaran IPA di SD mengembangkan keterampilan proses serta sikap ilmiah bagi siswa dalam menerima pengalaman dan pengetahuan baru yang lebih bermakna. Seiring dengan perkembangan teknologi, agar pembelajaran lebih kondusif untuk mewujudkan suasana belajar yang aktif, interaktif, dan menyenangkan.

Tujuan pembelajaran IPA di SD yaitu, siswa dapat memperoleh keyakinan terhadap kebesaran Tuhan Yang Maha Esa, siswa mengembangkan dan menerapkan dalam kehidupan sehari-hari konsep-konsep IPA yang bermanfaat, siswa mengembangkan rasa ingin tahu, sikap positif, dan kesadaran tentang hubungan antara IPA, lingkungan, teknologi, dan masyarakat, siswa mengembangkan keterampilan proses untuk memecahkan masalah dan mengambil keputusan tentang alam sekitar, siswa meningkatkan kesadaran untuk memelihara dan melestarikan lingkungan alam, siswa meningkatkan kesadaran untuk menghargai alam dengan segala 
keteraturannya, dan siswa memperoleh bekal pengetahuan, sikap, dan keterampilan untuk melanjutkan kejenjang SMP (KKD FIP Undiksha, 2018). Pembelajaran IPA di SD siswa akan mampu melatih keterampilan, pengetahuan dan sikap dalam mengenal diri sendiri maupun lingkungan sekitarnya. Pembelajaran IPA yang paling tepat untuk anak pada jenjang pendidikan sekolah dasar mereka diberikan kesempatan untuk melatih keterampilan-keterampilan proses IPA yang perlu dimodifikasi sesuai dengan tahap perkembangan kognitifnya. Lawe \& Meo (2018) menyatakan bahwa, anak usia 7 sampai 11 tahun merupakan usia anak yang memulai pendidikan pada jenjang sekolah dasar. Pada masa ini, siswa akan memahami sesuatu melalui tindakan yang termotivasi dengan sendirinya terhadap lingkungan.

Berdasarkan hasil wawancara terhadap guru-guru kelas IV SD Gugus V Kecamatan Sukasada tentang permasalahan pembelajaran IPA yaitu, nilai pada mata pelajaran IPA masih kurang, kurangnya media yang dipersiapkan oleh sekolah, kurang termotivasi dalam pembelajaran, dan guru jarang pengaplikasian model yang mampu menarik perhatian siswa. Pembelajaran yang demikian masih kurang efektif dalam menyampaikan sebuah materi pembelajaran bermakna yang akan memberikan pemahaman kepada siswa dalam pembelajaran. Pernyataan tersebut didukung dengan hasil observasi pada saat guru melaksanakan pembelajaran yaitu, guru lebih banyak menggunakan metode ceramah ,dan dalam pembelajaran hanya terjadi proses tanya jawab dan memberikan tugas, guru sudah menggunakan media namun belum maksimal sehingga pembelajaran kurang menarik dan perhatian siswa dalam belajar kurang baik, guru menggunakan pembelajaran berkelompok namun siswa masih kurang optimal dalam menyelesaikan permesalahan dalam bekerjasama, dan siswa kurang berani menyampaikan pendapat atau jawaban dalam mengikuti pembelajaran. Adapun pencatatan dokumen yang dilakukan untuk melegkapi hasil wawancara dan observasi tentang nilai ulangan tengah semester kelas IV pembelajaran IPA sebagai berikut.

Tabel 1

Data nilai ulangan tengah semester IPA siswa kelas IV SD

\begin{tabular}{llccccccc}
\hline No & Nama Sekolah & $\begin{array}{c}\text { Jumla } \\
\mathbf{h} \\
\text { Siswa }\end{array}$ & $\begin{array}{c}\text { Rata- } \\
\text { rata Nilai } \\
\text { UTS }\end{array}$ & KKM & $\begin{array}{c}\text { Siswa } \\
\text { Tuntas }\end{array}$ & $\%$ & $\begin{array}{c}\text { Siswa } \\
\text { Belum } \\
\text { Tuntas }\end{array}$ & $\%$ \\
\hline 1 & SDN 1 Panji & 38 & 57,37 & 60 & 11 & $29 \%$ & 27 & $71 \%$ \\
\hline 2 & SDN 2 Panji & 30 & 61,33 & 65 & 12 & $40 \%$ & 18 & $60 \%$ \\
\hline 3 & SDN 3 Panji & 21 & 65 & 60 & 17 & $80 \%$ & 4 & $19 \%$ \\
\hline 4 & SDN 4 Panji & 33 & 60,45 & 70 & 10 & $31 \%$ & 23 & $69 \%$ \\
\hline 5 & SDN 5 Panji & 22 & 61,14 & 68 & 5 & $23 \%$ & 17 & $77 \%$ \\
\hline 6 & SDN 6 Panji & 15 & 62,20 & 66 & 6 & $40 \%$ & 9 & $60 \%$ \\
\hline 7 & $\begin{array}{l}\text { SDN 1 } \\
\text { Sambangan }\end{array}$ & 20 & 61 & 72 & 4 & $20 \%$ & 16 & $80 \%$ \\
\hline 8 & $\begin{array}{l}\text { SDN 2 } \\
\text { Sambangan }\end{array}$ & 29 & 64,14 & 75 & 14 & $48 \%$ & 15 & $52 \%$ \\
\hline 9 & $\begin{array}{l}\text { SDN 3 } \\
\text { Sambangan }\end{array}$ & 28 & 58,57 & 65 & 11 & $39 \%$ & 17 & $61 \%$ \\
\hline$\quad \begin{array}{l}\text { Total } \\
\text { Rerata nilai UTS kelas } \\
\text { IV SD Gugus V }\end{array}$ & 236 & 551,2 & - & 90 & $38 \%$ & 146 & $62 \%$ \\
\hline & 61,24 & & & & & \\
\hline
\end{tabular}

Berdasarkan Tabel 1, hasil perhitungan rerata nilai ulangan tengah semester IPA SD kelas IV sebesar 61,24 jika dikonversikan dalam penilaian acuan patokan (PAP) menurut Agung, (2017:104) berada pada kategori tidak baik. Dilihat dari nilai KKM, dengan keseluruhan siswa 236 orang masih terdapat 146 orang siswa atau sama dengan 62\% di bawah nilai KKM. Berdasarkan kenyataan ini, masalah tersebut harus diatasi, dengan menggunakan salah satu model pembelajaran inovatif yaitu model pembelajaran ARCS. Karena model pembelajaran ARCS merupakan model pembelajaran yang mampu meningkatkan semangat dan motivasi belajar siswa 
serta akan berdampak terhadap meningkatnya hasil belajar siswa. Seperti yang dikemukakkan Putri et al., (2019) model pembelajaran ARCS dapat mempertahankan dan meningkatkan semangat belajar serta aktif dalam pembelajaran melalui tahapan-tahapan model pembelajaran ARCS.

Menurut Molaee \& Dortaj (2015) the ARCS model components are four categories. It means the same Attention, Relevance, Confidence, Satisfaction. These categories describe conditions for motivating persons. Sejalan dengan pendapat tersebut Keller (dalam Siregar \& Nara, 2010) menyatakan bahwa, seperangkat prinsip motivasi disusun dalam sebuah pembelajaran disebut sebagai model pembelajaran $A R C S$, yang dapat diterapkan dalam pembelajaran. Dari pendapat ahli di atas, apat disimpulkan bahwa model pembelajaran ARCS terdiri dari empat kategori perhatian, relevansi, kepercayaan diri, kepuasan merupakan model prinsip-prinsip motivasi dalam mendorong dan memepertahankan aktivitas siswa untuk semangat belajar. Model pembelajaran ARCS menumbuhkan semangat siswa dalam pembelajaran yang aktif, tidak jenuh, dan lebih mudah dalam memahami materi pembelajaran.

Siregar \& Nara (2010) menjelaskan keempat kondisi motivasional dengan beberapa tahapan yaitu, Attantion (perhatian) yaitu dorongan rasa ingin tahu. Perhatian siswa menjadi salah satu keberhasilan siswa dalam belajar (Nisa, 2017). Strategi untuk merangsang minat dan perhatian yaitu, menggunakan media dalam menyampaikan materi yang bervariasi serta melibatkan siswa dengan teknik bertanya, ada perlunya diselingi dengan humor yang dapat mempertahankan konsentrasi belajar siswa. Relenvance (Relevansi), yaitu adanya hubungan yang ditunjukkan antara materi pembelajaran dengan kondisi siswa. Motivasi belajar siswa terjadi apabila siswa dapat menemukan manfaat dari materi pembelajaran dalam kehidupan pribadi maupun nilai yang diyakini (Sari et al., 2018). Strategi yang dapat digunakan untuk menunjukkan relevansi dalam pembelajaran yaitu, dapat memberikan latihan/tes yang langsung berhubungan dengan kondisi siswa, menemukan manfaat pengetahuan yang dipelajari dan menyampaikan hasil yang didapat setelah mempelajari materi pembelajaran. Confidence (Kepercayaan diri), yaitu merasa diri kompeten atau mampu merupakan motivasi diri meningkat sejalan dengan harapan untuk berhasil. Senada dengan pendapat Nainggolan (2017) keyakinan akan kemampuan diri merupakan indikasi dari rasa percaya diri seseorang. Strategi untuk meningkatkan kepercayaan diri yaitu, meningkatkan harapan siswa untuk berhasil, tumbuh kembangkan kepercayaan diri siswa dengan pernyataan-pernyataan yang membangun, dan berikan umpan balik kontruktif selama pembelajaran, agar siswa mengetahui sejauh mana pemahaman dan potensi belajar mereka. Satisfaction (kepuasan) merupakan keberhasilan dalam mencapai suatu tujuan serta termotivasi untuk terus mencapai tujuan yang serupa. Hal ini dapat meningkatkan semangat siswa untuk berupaya lebih meningkatkan sikap positif ke arah pelajaran, serta menjadi bekal untuk mencapai tujuan-tujuan di masa depan (Yasir et al., 2017). Strategi untuk mencapai kepuasan yaitu, memberikan pujian secara verbal, umpan balik yang informatif, siswa yang telah menguasai untuk membatu teman-temannya yang belum berhasil, menyampaikan perubahan potensi siswa dari sebelumnya. Dengan keempat tahapan pembelajaran tersebut, respon siswa untuk belajar akan kembali tubuh serta konsentrasi, semangat untuk mencapai prestasi yang tinggi.

Model pembelajaran ARCS mempunyai kelebihan yaitu, memberikan arahan kepada siswa yang harus dilakukan. Berbagai cara yang menarik dilakukan dalam menyajikan materi. Penilaian dilakukan secara menyeluruh terhadap kemampuan dan karakteristik siswa (Sastrawan et al., 2017). Menurut Susanti, (2019) kelebihan model ARCS ini adalah berpusat pada empat komponen motivasi, guru menggunakan berbagai strategi dan metode dalam pembelajaran dalam menarik perhatian siswa untuk belajar. Relevansi antara meteri pembelajaran dengan realita sehingga peserta didik tertantang untuk memecahkan masalah yang ada sekaligus mereka dapat memiliki kesiapan dimasa mendatang. Rasa yakin dan nyaman dalam belajar serta adanya rasa puas dalam diri siswa ketika mereka sukses mendapati nilai dan tercapainya tujuan belajar

Simamora et al., (2020) menyatakan bahwa dalam penelitian yang dilakukan terdapat hal-hal yang baru dalam penggunaan model ARCS mampu membuat siswa untuk bangkit dan bertahan perhatian siswa dalam belajar artinya model pembelajaran ini menarik sehingga siswa di sibukkan dengan kegiatan didalamnya. Penelitian yang menyatakan bahwa model pembelajaran ARCS ini berpengaruh terhadap hasil belajar IPA yaitu penelitian yang dilakukan oleh Restuti et al., (2015) yang berjudul pengaruh model pembelajaran ARCS terhadap hasil belajar IPA siswa kelas VI SD. 
Hasil penelitiannya menyatakan bahwa terdapat perbedaan yang signifikan hasil belajar IPA yang dilihat dari perbedaan hasil belajar kedua kelompok penelitian. Pada nilai rata-rata hasil belajar IPA siswa kelompok eksperimen diketahui lebih tinggi dari pada nilai rata-rata hasil belajar siswa kelompok kontrol. Sehingga dapat disimpulkan bahwa terdapat perbedaan yang signifikan hasil belajar IPA antara siswa yang dibelajarkan dengan model pembelajaran ARCS dengan siswa yang dibelajarkan dengan pembelajaran konvensional. Serta penelitian yang dilakukan oleh Irsan (2018) menyatakan penerapan model pembelajaran ARCS dapat meningkatkan hasil belajar IPA, yang dapat dilihat dari nilai rata-rata siswa mengalami peningkatan yang signifikan setelah diadakan siklus II. Sehingga dapat disimpulkan bahwa terdapat pengaruh yang signifikan model pembelajaran ARCS terhadap hasil belajar IPA siswa kelas V SD. Penelitian yang dilakukan saat ini memiliki perbedaan yaitu model pembelajaran ARCS menekankan proses belajar teman sejawat, serta media yang digunakan untuk menjaga perhatian dan konsentrasi siswa menyesuaikan dengan materi dan kebutuhan siswa, sehingga siswa dapat menemukan manfaat materi pembelajaran dengan kehidupan pribadi. Sedangkan persamaannya yatu sama-sama mengkaji penggunaan model pembelajaran ARCS.

Berdasarkan permasalahan yang diuraikan di atas dapat diduga bahwa model pembelajaran ARCS berpengaruh terhadap hasil belajar IPA. Tujuan dan fokus penelitian ini yaitu untuk mengetahui Pengaruh Model Pembelajaran ARCS Terhadap Hasil IPA Siswa Kelas IV SD di Gugus V Kecamatan Sukasada Kabupaten Bueleleng Tahun Pelajaran 2019/2020.

\section{Metode}

Penelitian ini merupakan penelitian eksperimen yang bertujuan untuk mengetahui pengaruh model yang akan dibelajarkan terhadap hasil belajar siswa. Dalam penelitian ini, tidak semua variabel dapat dikontrol secara ketat selama pelaksanaan eksperimen. Maka dari itu, penelitian ini termasuk jenis penelitian eksperimen semu (quasi experimental). Disain penelitian yang digunakan dalam penelitian ini adalah non-equivalent post-test only control group design. Desain penelitian ini dipilih karena penelitian eksperimen semu tidak memungkinkan untuk merandom subjek yang ada pada setiap kelas secara utuh. Prosedur pelaksanaan desain penelitian ini terperinci pada Gambar 01.
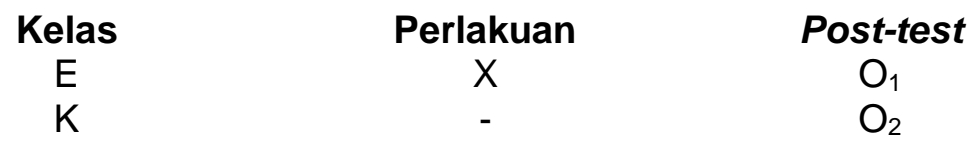

Gambar 1. Non-equivalent Post Test Only Control Group Design

(Sumber: dimodifikasi dari Gall, et al. dalam Agung, 2014:163)

Menurut Koyan (2012) populasi merupakan himpunan dari manusia, hewan, tumbuhan atau unsur-unsur yang sejenis dari unsur-unsur yang sejenis. Sedangkan Agung (2014) menyatakan bahwa populasi sebagai objek penelitan yang akan dilakukan. Berdasarkan pendapat ahli, dapat disimpulkan bahwa populasi adalah objek bisa berupa yang akan digunakan dalam suatu penelitian. Populasi pada penelitian ini adalah seluruh kelas IV SD Gugus V Kecamatan Sukasada dengan jumlah siswa 236 orang. Sampel merupakan bagian dari populasi yang menjadi bagian dari penelitian. Sejalan dengan ini Agung (2014) menyatakan bahwa sampel adawal perwakilan dari populasi yang dijadikan bahan perlakuan dalam penelitian yang di ambil dengan teknik sampling. Kemudian Koyan Koyan (2012:30) menyatakan bahwa "sampel penelitian adalah bagian dari populasi". Jadi dapat disimpulkan sampel merupakan bagian dari populasi.

Sebelum pengambilan sampel penelitian, terlebih dahulu melakukan uji kesetaraan hasil belajar siswa kelas IV SD Gugus V Kecamatan Sukasada. Uji kesetaraan menggunakan Analisis Varians Satu Jalur (Anava A) dengan kriteria jika $F_{\text {hitung }}<\mathrm{F}_{\text {tabel, }}$ maka $\mathrm{H}_{0}$ diterima dan $\mathrm{H}_{1}$ ditolak, sehingga kelompok tersebut diinterpretasikan setara. Hasil uji kesetaraan menunjukkan bahwa populasi dalam penelitian ini setara dengan harga $F_{\text {hitung }}<F_{\text {tabel, }}(1,34<1,98)$ pada taraf signifikansi 5\%). Setelah melakukan uji kesetaraan dilanjutkan dengan penentuan sampel menggunakan teknik kluster random sampling dengan cara undian. Dari 9 kelas yang diundi, diambil 2 kelas yang akan dijadikan sampel penelitian sebagai kelas eksperimen dan kelas kontrol, 
setelah dilakukan pengundian didapat kelas IV SD Negeri 2 Panji sebagai kelompok eksperimen dan kelas IV SD Negeri 4 Panji sebagai kelompok kontrol. Sebaran jumlah siswa dari kelas esksperimen dan kelas kontrol yaitu kelas IV SDN 2 Panji dengan jumlah siswa 30 orang sebagai kelompok eksperimen yang dibelajarkan dengan model pembelajaran ARCS dan kelas IV SDN 4 Panji dengan jumlah 33 orang sebagai kelompok kontrol dibelajarankan tanpa model pembelajaran ARCS.

Data yang dikumpulkan dalam penelitian ini adalah data tentang hasil belajar siswa pada pembelajaran IPA. Metode pengumpulan data hasil belajar mengggunakan metode tes dengan bentuk tes pilihan ganda. Tes pilihan ganda merupakan bentuk soal yang memberikan beberapa pilihan jawaban salah satunya terdapat jawaban yang benar. Menurut Setyawarno (2017) tes pilihan ganda merupakan bentuk soal yang menyediakan beberapa pilihan jawaban yang diantaranya terdapat jawaban yang benar. Tes pilihan ganda memiliki kekuatan tes yang memuat jawaban sebagai pengecoh diantara jawaban yang benar. Kekuatan tes pilihan ganda adalah pilihan jawaban yang dibuat saling berhubungan dan hamper tidak ketara sehingga jawaban sedikit menjadi benar (Suseno, 2017).

Instrumen penelitian yang digunakan pada penelitian ini adalah tes hasil belajar IPA dengan jumlah tes pilihan ganda yaitu sebanyak 25 butir soal. Dimana soal tersebut disusun sesuai dengan tingkat kesulitan berdasarkan domain Taksonomi Bloom Revisi (dalam Gunawan \& Palupi, 2016) proses kognitif berisikan enam kategori yaitu: C1 (mengingat), C2 (memahami), C3 (mengaplikasikan), C4 (menganalisis), C5 (mengevaluasi), dan C6 (mencipta). Dimensi pengetahuan berisikan empat kategori yaitu faktual, konseptual, prosedural, dan metakognitif.

Tes hasil belajar IPA sebelum digunakan, dilakukan uji validitas isi yang dilakukan oleh dua pakar yang membidangi IPA, setelah instrumen sudah dinyatakan relevan maka dilakukan uji coba untuk mengetahui apakah instrumen penelitian layak digunakan sebagai instrumen penelitian. sari dua kelompok penelitian dengan menghitung mean, median, modus, dan setandar deviasi. Hasil perhitungan anlisis deskriptif disajikan dalam grafik polygon untuk mengetahui kecendrungan skor hasil belajar IPA. Kurva polygon jika menggambarkan juling positif yang berarti sebagian besar skor cenderung rendah, apabila juling negatif yang berarti sebagian besar skor cenderung tinggi, dan apabila modus sama besarnya dengan median dan mean berarti sebaran data termasuk kurva normal.

Sedangkan analisis statistik inferensial ialah suatu cara pengolahan data untuk menguji suatu hitpotesis penelitian yang diajukan peneliti, serta mendapatkan kesimpulan berdasarkan hasil pengujian terhadap hipotesis (Agung, 2014). Sebelum dilakukan pengujian data yang diperoleh perlu diuji normalitasnya. Uji normalitas sebaran data dilakukan untuk menentukan data yang diperoleh apakah normal atau tidak. Uji normalitas sebaran data digunakan analisis chiSquare. Uji homogenitas varians dilakukan untuk mencari tingkat kehomogenan kelompok eksperimen dan kelompok kontrol. Untuk menguji homogenitas varians untuk kedua kelompok digunakan rumus uji Fisher (F). Setelah data yang diuji dengan uji prasyarat, jika terbukti bahwa kedua kelompok sampel berdistribusi normal dan homogen, maka pengujian selanjutnya adalah uji-t dengan rumus polled varians.

\section{Hasil dan Pembahasan}

Deskripsi data hasil penelitian ini memaparkan tentang data post-test hasil belajar IPA kelompok eksperimen dan kelompok kontrol. Data dalam penelitian ini mengenai hasil belajar IPA siswa kelas IV SD Gugus V Kecamatan Sukasada yang melibatkan dua kelompok siswa sebagai sampel penelitian. Data hasil belajar IPA pada kelompok eskperimen yang diperoleh melalui posttest terhadap 30 orang siswa dan pada kelompok kontrol dengan jumlah 33 orang siswa. Rangkuman deskripsi data hasil belajar IPA pada penelitian ini dapat dilihat pada Tabel 2. 
Tabel 2

Rangkuman perhitungan skor hasil belajar IPA

\begin{tabular}{lcc}
\hline \multirow{2}{*}{ Stastik Deskriptif } & \multicolumn{2}{c}{ Hasil Belajar IPA } \\
\cline { 2 - 3 } & Kelompok Eksperimen & Kelompok Kontrol \\
\hline $\mathrm{N}$ & 30 & 33 \\
\hline Mean & 18,83 & 16,12 \\
\hline Median & 19,5 & 16 \\
\hline Modus & 20 & 18 \\
\hline Standar Deviasi & 2,33 & 2,65 \\
\hline Varians & 5,46 & 7,03 \\
\hline Skor Tertinggi & 22 & 19 \\
\hline Skor Terendah & 13 & 12 \\
\hline Rentangan (range) & 11 & 8 \\
\hline
\end{tabular}

Berdasarkan Tabel 2, data hasil penelitian ini menunjukkan renge yaitu, 11 pada kelompok eksperimen dan 8 pada kelompok kontrol maka data disusun dalam tabel distribusi frekuensi tunggal. Berdasartkan hasil analisis deskriptif data, skor rata-rata hasil belajar IPA kelompok eksperimen lebih besar dibandingkan dengan kelompok kontrol. Untuk melihat kecenderungan skor hasil belajar IPA pada kelompok eksperimen dan kelompok kontrol disajikan kedalam grafik polygon.

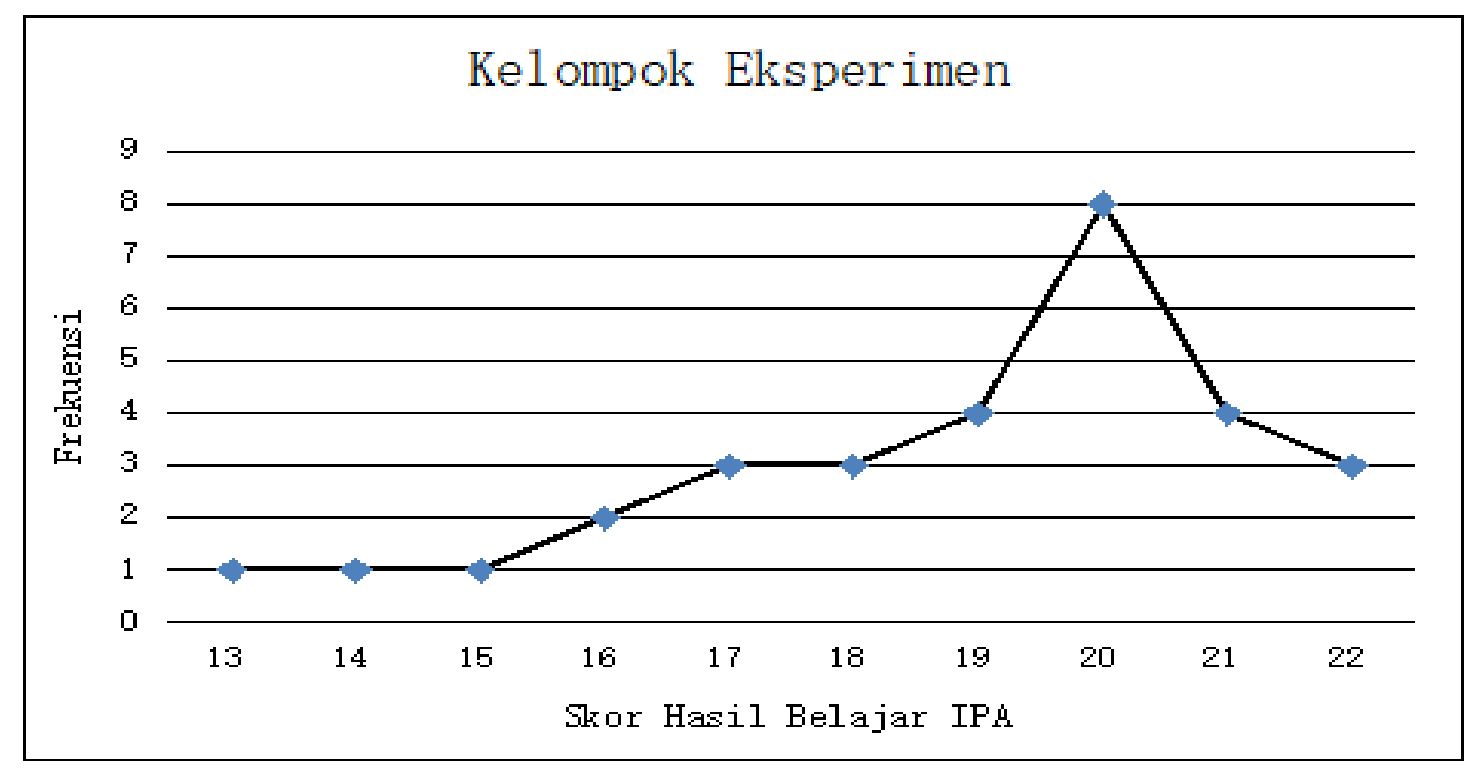

Gambar 2

Data Hasil Belajar IPA Kelas Eksperimen

Bedasarkan grafik polygon pada Gambar 2, tampak bahwa Mo>Me>M (20>19,5>18,83). Kurva tersebut digolongkan pada pada kurva juling negatif, hal ini menandakan bahwa skor post test pada kelompok eksperimen cenderung tinggi. Rata-rata hasil belajar IPA kelompok eksperimen yaitu 18,83 jika dikonversikan ke dalam PAP menurut Agung (2017:104) pada sekala lima maka berada pada kategori sangat baik, 


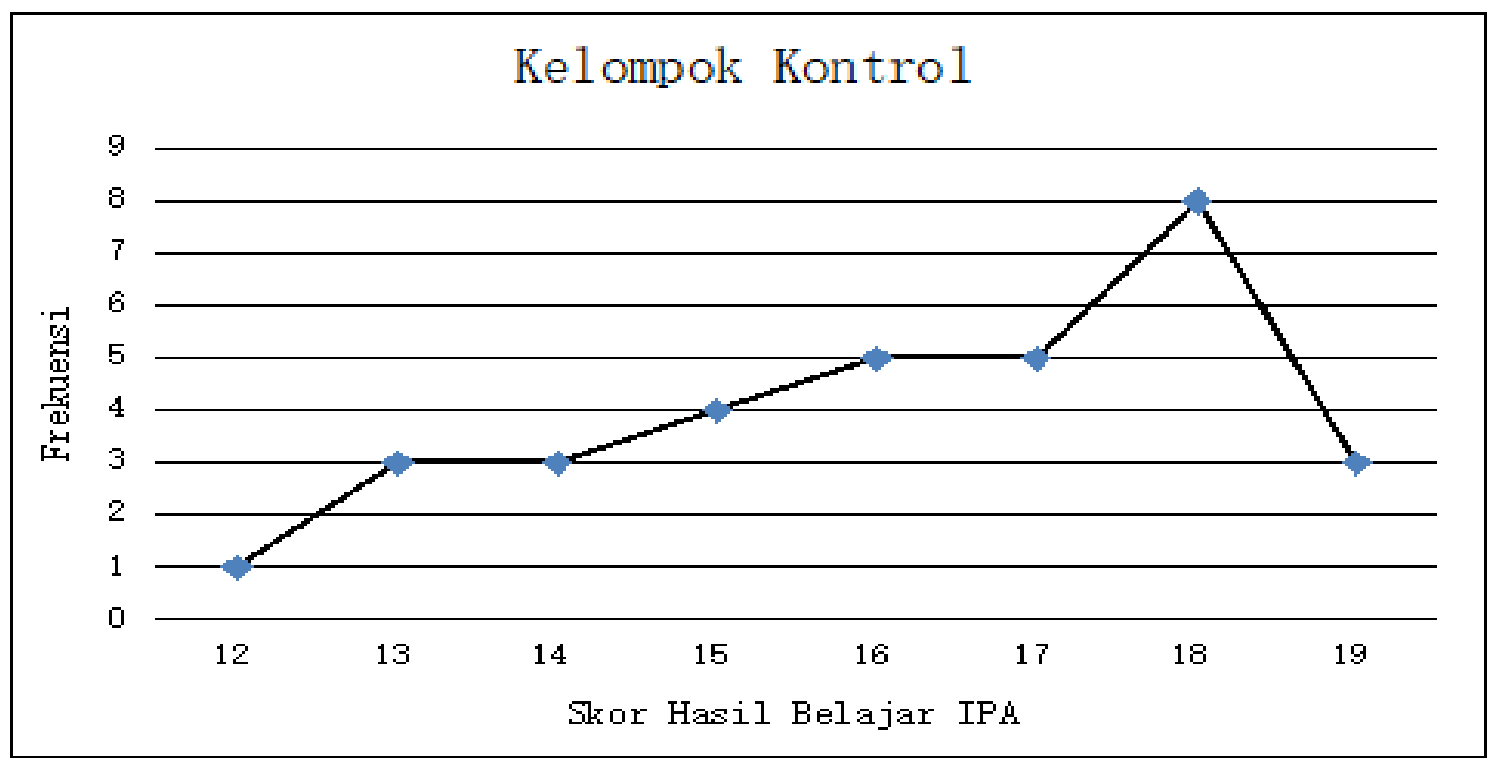

Gambar 3

Data Hasil Belajar IPA Kelas Kontrol

Bedasarkan kurva polygon pada Gambar 3, tampak bahwa Mo $>M>M e(18>16,12>16)$. Kurva tersebut di golongkan pada pada kurva juling negatif, hal ini menandakan bahwa skor post test pada kelompok kontrol cenderung tinggi. Rata-rata hasil belajar IPA kelompok kontrol adalah 16,12 yang dikonversikan ke dalam PAP menurut Agung (2017:104) pada sekala lima berada pada kategori baik.

Pengujian prasyarat dilakukan untuk memperoleh fakta apakah data memenuhi prasyarat uji normalitas dan uji homogenitas. Data yang diperoleh beridistribusi normal dan homogeny, sehingga hipotesis dianalisis menggunakan uji-t (pollend varians),

\section{Uji Normalitas}

Uji normalitas sebaran dilakukan untuk menyajikan bahwa sampel benar-benar berasal dari populasi yang berdistribusi normal. Uji normalitas data untuk skor hasil belajar IPA diuji dengan rumus Chi-Square $\left(X^{2}\right)$ dengan keriteria, jika harga $X^{2}$ hitung lebih kecil daripada $X^{2}$ tabel pada taraf signifikansi $5 \%$ dengan $\mathrm{dk}=$ (jumlah baris -1) maka data berdistribusi normal. Uji normalitas data dilakukan terhadap hasil post-test pada kelompok eksperimen dan kelompok kontrol.

Berdasarkan dari hasil perhitungan uji normalitas sebaran data dengan menggunakan bantuan Microsoft Excel 2013 for Wondows, uji normalitas sedaran data dengan rumus ChiSquare $\left(x^{2}\right)$ dilihat pada Tabel 3.

Tabel 3

Hasil uji normalitas sebaran data

\begin{tabular}{llllll}
\hline No & $\begin{array}{c}\text { Kelompok Data } \\
\text { Hasil belajar }\end{array}$ & $X^{2}$ hitung & $\begin{array}{c}\text { Nilai Kritis dengan Taraf } \\
\text { Signifikansi } 5 \%\end{array}$ & Status \\
\hline 1 & Kelompok Eksperimen & 7,69 & 11,07 & Normal \\
\hline 2 & Kelompok Kontrol & 8,08 & 11,07 & Normal \\
\hline
\end{tabular}

Berdasarkan Tabel 3, diperoleh $x^{2}$ hitung hasil post-test pada kelompok eksperimen sebesar 7,69. Sedangkan $X^{2}$ hitung hasil post-test pada kelompok kontrol sebesar 8,08 , dengan $\mathrm{dk}=$ jumlah baris $-1=6-1=5$, sehinnga didapat harga $X^{2}$ tabel sebesar 11,07 . Hasil hitung tersebut menunjukkan bahwa $X^{2}$ hitung hasil post-test pada kelompok eksperimen dan kelompok kontrol lebih kecil daripada $X^{2}$ tabel $\left(X^{2}\right.$ hitung $<X^{2}$ tabel $)$, sehingga dapat dinyatakan data yang diperoleh berdistribusi normal.

\section{Uji Homogenitas Varians}

Uji homogenitas varians dilakukan untuk mencari tingkat kehomogenan kelompok eksperimen dan kelompok kontrol. Untuk menguji homogenitas varians untuk kedua kelompok 
digunakan rumus uji Fisher $(F)$ dengan kriteria data homogen jika $F_{\text {hitung }}<F_{\text {tabel }}$ pengujian dilakukan pada taraf signifikansi $5 \%$ dengan derajat kebebasan untuk pembilang $\mathrm{dk} 1=\mathrm{k}-1$ dan derajat kebedasan untuk pengebut $\mathrm{dk} 2=\mathrm{n}-\mathrm{k}$.

Berdasarkan dari hasil perhitungan uji homogenitas varians dengan menggunakan bantuan Microsoft Excel 2013 for Wondows, hasil uji homogenitas varians dengan Uji-F dapat dilihat pada tabel 4.

Tabel 4

Hasil Uji Homogenitas Varians antar Kelompok Eksperimen dan Kelompok Kontrol

\begin{tabular}{ccccc}
\hline Sumber Data & Varians & $F_{\text {hitung }}$ & $\begin{array}{c}F_{\text {tabel }} \text { dengan taraf } \\
\text { signfikasi 5\% }\end{array}$ & Status \\
\hline Kelompok Eksperimen & 5,46 & \multirow{2}{*}{1,28} & 4,00 & Homogen \\
\hline Kelompok Kontrol & 7,03 & & 4,00
\end{tabular}

Berdasarkan Tabel 4, $\mathrm{F}_{\text {hitung }}$ hasil belajar IPA kelompok eksperimen dan kelompok kontrol adalah 1,28 . Sedangkan $F_{\text {tabel }}$ dengan $d_{b} b_{\text {pembilang }}=1, d_{\text {penyebut }}=61$ pada taraf sgnifikansi $5 \%$ adalah 4,00. Hai ini menunjukkan bahwa $F_{\text {hitung }}<F_{\text {tabel }}(1,28<4,00)$ sehingga, dapat dinyatakan data yang diperoleh homogen.

\section{Uji Hipotesis}

Berdasarkan uji prasyarat yaitu uji normalitas sebaran data dan uji homogentias varians diperoleh hasil belajar IPA bahwa data dari kelompok eksperimen dan kelompok kontrol berdistribusi normal dan bersifat homogen. Uji prasyarat sudah terpenuhi maka dilanjutkan dengan pengujian hipotesis dilakukan dengan uji-t (polled varians). Karena $n_{1} \neq n_{2}$ dan varians homogen, maka $\mathrm{db}=\left(\mathrm{n}_{1}+\mathrm{n}_{2}\right)-2$ dengan kriteria pengujian $\mathrm{H}_{0}$ ditolak jika thitung $>\mathrm{t}_{\text {tabel }}$ dan $\mathrm{H}_{0}$ diterima thitung $<$ $t_{\text {tabel. }}$ Untuk ringkasan hasil analisis uji-t dapat dilihat pada Tabel 5.

Tabel 5

Hasil Analisis Uji-t

\begin{tabular}{ccccccc}
\hline Kelompok & $\mathbf{n}$ & $\mathbf{d b}$ & Mean $(\bar{x})$ & $\mathbf{s}^{\mathbf{2}}$ & $\mathbf{t}_{\text {hitung }}$ & $\mathbf{t}_{\text {tabel }}$ \\
\hline Eksperimen & 30 & \multirow{2}{*}{61} & 18,83 & 5,46 & \multirow{2}{*}{4,37} & \multirow{2}{*}{2,00} \\
\cline { 1 - 1 } & 33 & & 16,12 & 7,03 & \\
\hline Kontrol & & & &
\end{tabular}

Analisis uji-t untuk hasil belajar siswa pada pembelajaran IPA dengan rumus polled varians, diperoleh $t_{\text {hitung }}=4,37$. Sedangkan $t_{\text {tabel }}$ untuk $d b=\left(n_{1}+n_{2}\right)-2=61$ pada taraf sgnifikansi $5 \%$. Hasil perhitungan tersebut menyatakan thitung $>t_{\text {tabel }}(4,37>2,00)$. Dengan demikian, dinyatakan bahwa terdapat pengaruh yang signifikan model pembelajaran Attention, Relevance, Confidence, Satisfaction (ARCS) terhadap hasil belajar IPA siswa kelas IV di SD Gugus V Kecamatan Sukasada Kabupaten Buleleng Tahun Pelajaran 2019/2020.

\section{Pembahasan}

Berdasarkan pengujian hipotesis dengan uji-t pada taraf sgnifikansi 5\% diperoleh nilai thitung $>t_{\text {tabel }}(4,37>2,00)$. Hasil perhitungan tersebut menunjukkan bahwa terdapat pengaruh yang signifikan model pembelajaran ARCS terhadap hasil belajar IPA siswa kelas IV di SD Gugus V Kecamatan Sukasada Kabupaten Buleleng Tahun Pelajaran 2019/2020. Selama pelaksanaan penelitian pada kelas IV SD Gugus V Kecamatan Sukasada Kabupaten Bueleleng khususnya pada kelompok eksperimen berjalan dengan optimal dan efektif. Sebelum diberikan perlakuan, skor hasil belajar IPA pada kelompok eksperimen dan kelompok kontrol memiliki kemampuan yang setara, setelah diberikan perlakuakuan pada kelompok eksperimen terdapat perbedaan skor hasil belajar IPA. Rata-rata skor hasil belajar kelompok eksperimen lebih tinggi dari kelompok kontrol. Selain itu, adapun yang mendasari dari keberhasilan pembelajaran model pembelajaran ARCS pada kelompok eksperimen adalah sebagai berikut.

Pertama, model pembelajaran ARCS merupakan model pembelajaran yang mempertahankan aktivitas dan motivasi siswa dalam belajar serta memberikan lingkungan belajar 
yang mempu menciptakan proses belajar aktif. Attention, pada tahap meningkatkan konsentrasi dan menarik perhatian siswa dilakukan beberapa strategi yaitu, dalam penyampaian materi pembelajara IPA dilakukan dengan teknik bertanya dan diskusi kelompok, dengan demikian dalam sebuah diskusi terjadinya alur pengolahan informasi yang dilakukan seluruh anggota kelompok. Guru memiliki tugas sebagai motivator dan fasilitator dalam kegiatan diskusi. Model pembelajaran $A R C S$ dibantu dengan media power point untuk memudahkan menyampaian materi pembelajaran IPA. Dalam menggunakan media power point yang menerangkan tentang percobaan macammacam gaya dan gambar dan video pembelajaran, dengan itu perhatian dan konsentrasi siswa dalam belajar terpelihara dengan baik. Melalui kegiatan tersebut, konsentrasi belajar siswa akan terpelihara seterusnya sehingga siswa akan semangat dan termotivasi dalam mencpai kepuasan dalam belajar. Temuan ini sejalan dengan pendapat Hermaswari et al., (2019) Attentrion (perhatian) harus dibangkitkan dan dipertahankan dalam pembelajaran.

Kedua, Relevance, pada tahap ini guru menyesuaikan antara materi pembelajaran yang disajikan dengan pengalaman belajar siswa. Dengan menciptakan ruang diskusi dalam sebuah kelompok dengan dan berikan tes/latihan berupa LKPD percobaan sesuai dengan kondisi siswa. Dalam menyelesaikan masalah, siswa akan belajar bagaimana cara bermusyawarah untuk mendapatkan suatu keputusan. Guru mengarahkan siswa agar saling membantu apabila terdapat teman mengalami kesulitan dalam mencerna mataeri diskusi. Dengan demikian siswa mengetahui manfaat langsung keterkaitan antara materi pembelajaran IPA dengan kehidupan sehari-hari. Motivasi belajar tumbuh ketika siswa menemukan manfaat materi pembelajaran IPA yang dipelajari memiliki hubungan dengan kehidupan pribadi siswa. Pada akhir diskusi siswa mensimulasikan kegiatan percobaan yang telah didiskusikan dalam sebuah lembar kerja yang telah diberikan. Siswa atau kelompok lain diberikan kesempatan untuk menanggapi atau menambahkan jawaban dari hasil dikusi kelmpok mereka. Meningkatkan keberanian siswa dalam menyampaikan pendapat dan pertanyaan dapat melatih kepercayaain diri siswa dalam proses belajar. Kepercayaan diri siswa dan harapan untuk berasil dalam menanggapi maupun menambahkan jawaban sangat penting dan harus dipertahankan agar siswa memiliki harapan untuk berhasil dan nyaman dalam proses belajar. Penemuan ini sejalan dengan pendapat Putri et al., (2019) menyatakan bahwa, menghubungkan materi pembelajaran dengan kehidupan sehatihari siswa akan berdampak pada kepercayaan diri siswa dalam mencapai tujuan belajarnya.

Ketiga, mencapai kepuasan dan keberhasilan dalam mencapai suatu tujuan belajar. Siswa mampu menarik kesimpulan dari beberapa permasalahan dalam proses diskusi, sehingga siswa akan mengetahui bagaimana manfaat materi pembelajaran IPA dengan kehidapan sehari-hari siswa. Tercapainya hal tersebut siswa merasa puas dan berasil dalam mencapai tujuan pembelajaran IPA yang berlangsung dengan optimal. Guru memberikan pujian secara verbal, memberi dorongan, senyuman, anggukan dan pandangan yang simanatik atas partisipasi siswa. Siswa yang telah berhasil mencapai tujuan belajar untuk membatu teman sebaya yang mengalami kesulitan dalam memahami materi yang belum dikuasai. Penemuan ini sejalan dengan pendapat Jamil (2019) rasa puas siswa dalam belajarnya dapat untuk mengelola penguatan intrinsik dan ekstrinsik.

Kelebihan model pembelajaran ARCS memiliki kelebihan yang mampu meningkatkan motivasi dan mempertahankan aktivitas siswa. Adapun kelebihan model pembelajaran ARCS menurut Sastrawan et al., (2017) yaitu, memberikan petunjuk, aktif dan memberi arahan tentang apa yang harus dilakukan oleh siswa. Cara penyajian materi dengan model ARCS ini bukan hanya dengan teori yang penerapannya kurang menarik. Model motivasi yang diperkuat oleh rancangan bentuk pembelajaran berpusat pada siswa. Penilaian menyeluruh terhadap kemampuan-kemampuan yang lebih dari karakteristik siswa-siswa agar strategi pembelajaran lebih efektif.

Berbeda halnya dengan pembelajaran pada kelompok kontrol. Adapun hasil temuan yang didapatkan yaitu pembelajaran masih menggunakan gaya pembelajaran yang berpusat pada guru akan berdampak kepada kurangnya motivasi belajar sehingga siswa tidak aktif dalam pembelajaran. Guru masih mendominasi dalam kegiatan belajar siswa dan meberikan pengetahuan dengan metode ceramah. Tugas siswa hanya mencatat, mendengar dan menghapal. Guru sudah menerapkan kegiatan pembelajaran berkelompok namun belum terlaksana dengan maksimal, guru hanya memanggil satu persatu siswa untuk membaca materi di depan kelas secara bergantian. Kegiatan pembelajaran seperti ini, siswa tidak memiliki kesempatan untuk 
bertukar pikiran antar teman sejawat, serta akan menimbulkan rasa bosan ketika berlangsungnya pembelajaran.

Berdasarkan temuan yang didapatkan dari kelompok eskperimen maupun kelompok kontrol, hasil belajar IPA yang dibelajarkan dengan model pembelajaran ARCS menunjukkan hasil yang signifikan lebih baik dibandingkan dengan kelompok siswa yang tanpa dibelajarkan dengan model pembelajaran ARCS karena disebabkan adanya perbedaan perlakuan pada langkah-langkah pembelajaran serta dengan memepertahankan konsentrasi dan motivasi belajar siswa yang menumbuhkan keaktifan siswa dalam meraih kepuasan belajar sehingga berdampak positif terhadap hasil belajar IPA. Penemuan ini sejalan dengan pendapat pakar Keller (dalam Siregar \& Nara, 2010) menyatakan bahwa, seperangkat prinsip motivasi disusun dalam sebuah pembelajaran disebut sebagai model pembeajaran $A R C S$, dan juga didukung dengan hasil penelitian yang dilakukan oleh Yulianti et al., (2019) menyatakan bahwa, model pembelajaran ARCS memberikan petunjuk, aktif dan memberikan arahan tentang apa yang harus dilakukan oleh siswa dan model motivasi yang diperkuat oleh rancangan untuk pembelajaran berpusat pada siswa. Selain itu, materi pembelajaran dapat dimodifikasi menjadi lebih menarik dan mudah dipahami, serta suasana pembelajaran yang menegangkan akan menjadi menyenangkan pada akhirnya dapat meningkatkan hasil belajar IPA sesuai dengan tujuan yang diharapkan. Hal tersebut dapat memberikan kontribusi yang baik terhadap meningkatkan hasil belajar IPA.

Hasil penelitian ini diperkuat dengan penelitian yang dilakukan oleh Fitriani \& Hera (2019) yang menunjukkan dengan model ARCS berpengaruh yang signifikan terhadap hasil belajar siswa. Penelitian lain yang mendukung yaitu oleh Sukarno \& Salamah (2019) terdapat perbedaan hasil belajar yang signifikan antara yang diajar dengan menggunakan model ARCS dengan model konvensional. Selain itu, juga didukung dengan penelitian oleh Alfiyana et al., (2018) yang menunjukkan pembelajaran menggunakan model ARCS dengan berpengaruh yang signifikan terhadap motivasi dan hasil belajar siswa. Serta, berdasarkan hasil temuan pada penelitian ini, yaitu dapat dinyatakan bahwa terdapat pengaruh yang signifikan model pembelajaran ARCS terhadap hasil belajar IPA siswa kelas IV di SD Gugus V Kecamatan Sukasada Kabupaten Buleleng Tahun Pelajaran 2019/2020

\section{Simpulan}

Berdasarkan hasil penelitian dan pembahasan di atas, dapat disimpulkan terdapat pengaruh yang signifikan model pembelajaran Attention, Relevance, Confidence, Satisfaction (ARCS) terhadap hasil belajar IPA siswa kelas IV di SD Gugus V Kecamatan Sukasada Kabupaten Buleleng Tahun Pelajaran 2019/2020. Hal ini dapat dilihat pada hasil uji-t menunjukkan bahwa nilai thitung $=4,37$ dan untuk tabel dengan $(\mathrm{db})=61$ pada taraf sgnifikansi $5 \%$ diperoleh nilai tabel $=2,00$, dengan perbandingan $t_{\text {hitung }}>t_{\text {tabel }}$. Adanya perbedaan yang signifikan menunjukkan bahwa model pembelajaran ARCS berpengaruh terhadap hasil belajar IPA siswa kelas IV SD Gugus V Kecamatan Sukasada Kabupaten Buleleng Tahun Pelajaran 2019/2020. Berdasarkan pada hasil penelitian yang diperoleh, saran yang dapat diajukan sebagai tindak lanjut dari penelitian ini yaitu, siswa-siswa di sekolah dasar agar selalu semangat serta menumbuhkan motivasi belajar dalam setiap keberlangsungan pembelajaran untuk memperoleh pengalaman baru yang lebih bermakna dalam meningkatkan hasil belajar. Kepada guru agar dapat menggunakan berbagai model pembelajaran yang inovatif dalam upaya meningkatkan hasil belajar siswa. Salah satu alternatif yang dapat digunakan dalam pembelajaran yaitu model pembelajaran ARCS karena dapat merangsang siswa semangat dan motivasi belajar dan akan berdampak pada pencapaian hasil belajar yang maksimal. Kepada kepala sekolah sebagai pembuat kebijakan, dapat memberikan bimbingan dan motivasi dalam usaha peningkatan kualitias pembelajaran dengan model inovatif. Kepada peneliti lain, hasil penelitian ini diharapkan dapat dijadikan sebagai salah satu acuan kajian pustaka untuk melakukan penelitian dalam variabel yang sama maupun variabel yang berbeda.

\section{Daftar Pustaka}

Jurnal Mimbar IImu | 305 
Agung, A. A. G. 2014. Metodologi Penelitian Pendidikan. In Malang: Aditya Media Publishing.

Agung, A. A. G. 2017. Evaluasi Pendidikan. Singaraja: Undiksha.

Alfiyana, R., Sukaesih, S., \& Setiati, N. (2018). Pengaruh model ARCS (Attention, Relevance, Confidence, Satisfaction) dengan metode talking stick terhadap motivasi dan hasil belajar siswa materi sistem pencernaan makanan. Journal of Biology Education, 7(2), 226-236.

Ariyanto, M. (2016). Peningkatan Hasil Belajar IPA Materi Kenampakan Rupa Bumi Menggunakan Model Scramble. Profesi Pendidikan Dasar, 3(2), 134-140.

Fitriani, N., \& Hera, R. (2019). Pengaruh Model Pembelajaran ARCS (Attention, Relavance, Confidance, Satisfaction) Terhadap Peningkatan Aktvitas dan Hasil Belajarsiswa Pada Materi Sistem Pernapasan Manusia di SMP Negeri 5 Seunagan Kabupaten Nagan Raya. Bionatural: Jurnal IImiah Pendidikan Biologi, 6(1).

Gunawan, I., \& Palupi, A. R. (2016). Taksonomi Bloom-revisi ranah kognitif: kerangka landasan untuk pembelajaran, pengajaran, dan penilaian. Premiere Educandum: Jurnal Pendidikan Dasar Dan Pembelajaran, 2(02).

Hermaswari, M. S, dkk. (2019). Pengaruh Model Pembelajaran Attention, Relevance, Confidence, and Satisfaction (ARCS) Terhadap Aktivitas Dan Hasil Belajar IPS Terpadu Di SMP N 2 Sawan. Jurnal Pendidikan Ekonomi Undiksha, 10(1), 136.

IRSAN, I. (2018). Penerapan Model ARCS (Attention, Relevance, Confidence, Satisfaction) Untuk Meningkatkan Hasil Belajar IPA Murid Kelas V SDN Topa Baubau. Socioedu Journal (Pendidikan, Sosial, Humaniora), 2(1).

KKD FIP Undiksha. 2018. Pendidikan IPA. Singaraja: Undiksha.

Koyan, I. W. 2012. Statistik pendidikan teknik analisis data kuantitatif. Singaraja: Universitas Pendidikan Ganesha Press.

Lawe, Y. U., \& Meo, M. I. K. (2018). Pengembangan perangkat pembelajaran IPA kelas IV berbasis nature of science dengan model dick and carey. Jurnal IImiah Pendidikan Citra Bakti, 5(2), 26-35.

Mawardi, M., \& Mariati, M. (2016). Komparasi Model Pembelajaran Discovery Learning dan Problem Solving Ditinjau dari Hasil Belajar IPA pada Siswa Kelas 3 SD di Gugus DiponegoroTengaran. Scholaria: Jurnal Pendidikan Dan Kebudayaan, 6(1), 127-142.

Mekka Madaina Jamil. (2019). Optimalisasi Model ARCS Dalam Pembelajaran Saintifik Untuk Meningkatkan Motivasi Belajar Peserta Didik Pada Peminatan Mata Pelajaran Geografi Di Kelas Matematika IImu Alam. IJIS Edu : Indonesian Journal Of Integrated Science Education,

Molaee, Z., \& Dortaj, F. (2015). Improving L2 learning: An ARCS instructional-motivational approach. Procedia-Social and Behavioral Sciences, 171, 1214-1222.

Nainggolan, T. (2017). Hubungan Antara Kepercayaan Diri Dengan Kecemasan Sosial Pada Pengguna Napza: penelitian di balai kasih sayang parmadi siwi. Sosio Konsepsia, 16(2), 161174.

Nariastini, N. L. P. S, dkk. (2015). Pengaruh Strategi Pembelajaran Inkuiri Berbantuan Media Lingkungan Sekitar Terhadap Hasil Belajar IPA Kelas IV. MIMBAR PGSD Undiksha, 3(1).

Nisa, A. (2017). Pengaruh Perhatian Orang Tua dan Minat Belajar Siswa Terhadap Prestasi Belajar Ilmu Pengetahuan Sosial. Faktor Jurnal IImiah Kependidikan, 2(1), 1-9.

Pane, A., \& Dasopang, M. D. (2017). Belajar dan pembelajaran. Fitrah: Jurnal Kajian IImu-IImu Keislaman, 3(2), 333-352.

Putra, P. (2017). Pendekatan Etnopedagogi dalam Pembelajaran IPA SD / MI. Primary Education Journal (PEJ), 1(1), 17-23.

Putri, I. N., dkk. (2019). Pengaruh Model Pembelajaran ARCS ( Attention, Relevance, Confidence 
, Satisfaction ) Terhadap Self Esteem. Natural Science Education Reseach, 2(1), 1-7.

Restuti, N. L. , dkk. (2015). Pengaruh Model Pembelajaran ARCS Terhadap Hasil Belajar IPA Siswa Kelas VI SDN 11 Sesetan Tahun Pelajaran 2014/2015. MIMBAR PGSD Undiksha, $3(1)$.

Sari, N., dkk. (2018). Analisis Motivasi Belajar Siswa dalam Pembelajaran Fisika Sekolah Menengah Atas. Jurnal Pendidikan Dan Kebudayaan, 3(1).

Sastrawan, G. Y., dkk. (2017). Pengaruh Model ARCS (Attention, Relevance, Confidence, Satisfaction) Terhadap Hasil Belajar IPA Dengan Mengontrol Motivasi Berprestasi Pada Siswa Kelas V Semester Genap SD Triamerta Tahun Pelajaran 2016/2017. MIMBAR PGSD Undiksha, 5(2).

Setiyawati, E., \& Rocmah, L. I. (2017). Peningkatan Karakter Mahasiswa Program Studi PGSD pada Mata Kuliah Pengembangan Pembelajaran IPA SD di Universitas Muhammadiyah Sidoarjo. PEDAGOGIA: Jurnal Pendidikan, 6(1), 32-42.

Setyawarno, D. (2017). Penggunaan Aplikasi Software Iteman (Item and Test Analysis) untuk Analisis Butir Soal Pilihan Ganda Berdasarkan Teori Tes Klasik. JIFP (Jurnal IImu Fisika Dan Pembelajarannya), 1(1), 11-21.

Simamora, L., Hernaeny, U., \& Safitri, N. D. (2020). Pengaruh Model Pembelajaran Attention, Relevance, Confidence, Satisfaction (ARCS) terhadap Kemampuan Pemecahan Masalah Matematika. JKPM (Jurnal Kajian Pendidikan Matematika), 5(2).

Siregar, E., \& Nara, H. 2010. Teori Belajar dan Pembelajaran Ghalia Indonesia. Jakarta.

Sukarno, S., \& Salamah, S. (2019). Pengaruh Model Pembelajaran ARCS (Attention, Relevance, Confidence, Satisfaction.) dan Motivasi Terhadap Hasil Belajar IPS Siswa Kelas V SD Negeri 75 Kota Bengkulu. At-Ta'lim : Media Informasi Pendidikan Islam, 18(1), 137.

Susanti, L. (2019). Hubungan Nilai Pretest dan Postest Pada Pembelajaran Model Motivasi Attention Relevance Confidence Satisfaction (ARCS) Siswa Kelas 1 SD CHARIS Malang. SNHRP, 50-54.

Suseno, I. (2017). Komparasi Karakteristik Butir Tes Pilihan Ganda Ditinjau Dari Teori Tes Klasik. Faktor Jurnal IImiah Kependidikan, 4(1), 1-8.

Yasir, M., Suarman, \& Gusnardi. (2017). Analisis Tingkat Kepuasan Siswa dan Motivasi Dalam Pembelajaran Kelompok (Cooperative Learning) dan Kaitannya Dengan Hasil Belajar Akuntansi di SMK Labor Binaan FKIP UNRI Pekanbaru. Jurnal Pekbis, Volume 9(2), 77-90.

Yulianti, Y., dkk. (2019). Pengaruh Penerapan Model Pembelajaran Attention, Relevance, Confidence, Satisfaction (ARCS) terhadap Motivasi Belajar dan Hasil Belajar Siswa pada Materi Kalor di Kelas X. Variabel, 2(1), 24-30. 